\title{
Pengaruh Penambahan Gurney Flap pada Airfoil Jenis Mshd pada Mobil Fastback dengan Variasi Ketinggian Gurney Flap dan Kemiringan Sudut Airfoil Dengan Metode Permodelan CFD
}

\author{
Naufal Ikhsan Alfajri ${ }^{1}$, Dominicus Danardono ${ }^{1}$, Budi Kristiawan ${ }^{1}$ \\ ${ }^{1}$ Program Studi Teknik Mesin - Universitas Sebelas Maret \\ e-mail address : Naufalikhsanalfajri@gmail.com
}

\begin{tabular}{l} 
Keywords: \\
\hline Fastback, Aerodinamika, \\
Rear wing, Gurney Flap, \\
Airfoil, MSHD Airfoil, \\
Computational Fluid \\
Dynamic (CFD), Ahmed \\
body.
\end{tabular}

\section{PENDAHULUAN}

Aerodinamika otomotif merupakan studi aerodinamika untuk kendaraan darat (ground vehicle). Tujuan utama dari studi ini adalah mengurangi gaya hambatan (drag), meningkatkan penghematan bahan bakar, mencegah gaya angkat (lift) yang tidak diinginkan, dan meminimalkan penyebab ketidakstabilan aerodinamik lainnya pada kecepatan tinggi. Selain itu, memperhitungkan faktor aerodinamis pada desain kendaraan darat untuk mendapatkan kontrol yang baik pada kemudi dan pengereman [1].

Pada kecepatan tinggi, gaya angkat (lift) pada suatu mobil dapat membuat ban mobil menjadi terangkat sehingga ban kurang mencekam permukaan tanah dan menyebabkan mobil sulit untuk dikendalikan dan menjadi tidak stabil [2].

pada tahun 1965 Jim Hall memperkenalkan penggunaan airfoil yang disusun terbalik pada mobil sport Chaparral-nya untuk mengembangkan aerodinamis downforce dan memberikan pengereman aerodinamis.
Berkebalikan dengan lift, downforce merupakan gaya dari udara yang menekan sisi bagian atas mobil agar roda selalu menempel dengan tanah, sehingga mengurangi slip antara roda dan tanah ketika dalam kecepatan tinggi [3].

Berbagai komponen aerodinamis telah diteliti secara beragam pada peningkatan downforce. Namun, hanya airfoil depan dan belakang serta sayap depan dan belakang pada mobil yang memberikan metode analisis aerodinamis secara teoritis [4]. Tetapi, seperti yang telah disoroti oleh Agathangelou dan Gascoyne [5], penelitian aliran sayap maupun airfoil bagian depan dipersulit oleh faktor tanah (karena jaraknya dekat dengan tanah) dan dekat dengan roda depan. Oleh karena itu, penelitian komponen aerodinamis bagian depan baik sayap maupun airfoil sulit untuk dilakukan dengan metode teoritis yang sudah ada. Untuk sayap bagian belakang, terlihat aliran yang relatif lebih 'bersih' karena terpasang lebih tinggi dari badan kendaraan dan tidak ada bagian lain dari kendaraan, sehingga memungkinkan penelitian

https://dx.doi.org/10.20961/mekanika.v19i1.40005 
untuk fokus mencari downforce yang nilainya akan tinggi pada bagian tersebut. Oleh karena itu, profil sayap belakang menjadi lebih mudah, karena tidak ada kompromi desain aerodinamis lainnya yang masuk ke bagian perhitungan.

Airfoil dengan hasil lift yang tinggi, memiliki beberapa kekurangan seperti kerumitan desain, kesulitan produksi, dan biaya perawatan, sehingga sulit untuk diaplikasikan secara massal dalam pesawat komersial maupun militer. Oleh karena itu, ada metode yang sering digunakan yaitu menambahkan perangkat sederhana seperti Gurney Flap (GF) untuk meningkatkan kinerja aerodinamis airfoil. Pengemudi mobil balap Dan Gurney, menggunakan flap ini pada airfoil yang disusun secara terbalik untuk meningkatkan downforce, sehingga meningkatkan daya cekam ban selama akselerasi, pengereman, dan menikung [6].

Wang [6]merangkum beberapa penelitian tentang pengaruh Gurney Flap terhadap koefisien lift dan drag pada suatu airfoil. Salah satunya, tentang pengaruh Gurney Flap pada airfoil dengan variasi ketinggian yang diambil dari presentase nilai chord line (\%c) dari airfoil NACA0012 terhadap nilai koefisien lift dan drag. Ketinggian yang dipakai pada penelitian ini yaitu $0,5 \% \mathrm{c}, 1 \% \mathrm{c}, 1,5 \% \mathrm{c}, 2 \% \mathrm{c}$, dan $3 \% \mathrm{c}$. Hasilnya, untuk nilai koefisien lift dan drag terbesar, tentu saja didapatkan pada ketinggian $3 \%$ c, namun untuk nilai $C_{L} / C_{D}$ terbesar terdapat pada ketinggian $2 \% \mathrm{C}$ dengan nilai $35 \%$. Selain itu, untuk ketinggian 3\%c juga terjadi stall atau penurunan yang cukup tajam setelah $C_{L}$ mencapai nilai 1.75 . Oleh karena itu, dapat disimpulkan apabila Gurney Flap memiliki ketinggian diatas $2 \%$ c hanya akan meningkatkan nilai drag yang cukup tinggi.

Pakkam [4] melakukan penelitian pengaruh airfoil jenis MSHD terhadap koefisien lift dan drag menggunakan wind tunnel dan XFOIL pada bilangan Reynolds 300.000 atau sekitar $33 \mathrm{mph}$ dan membandingkannya dengan beberapa jenis airfoil lainnya. Hasilnya, nilai downforce airfoil MSHD lebih stabil dibandingkan dengan airfoil Wortmann FX74-C15-140 dan Selig 1223 seiring dengan kemiringan sudut yang diberikan.

\section{METODOLOGI PENELITIAN}

Penelitian ini bertujuan untuk mengetahui pengaruh penambahan Gurney Flap pada rear wing mobil tipe fastback terhadap peforma aerodinamis mobil. Penelitian ini menggunakan geometri permodelan Ahmed body untuk menyederhanakan bentuk mobil tipe fastback dengan aplikasi permodelan 3D Ansys Fluent.

\section{Perancangan Model}

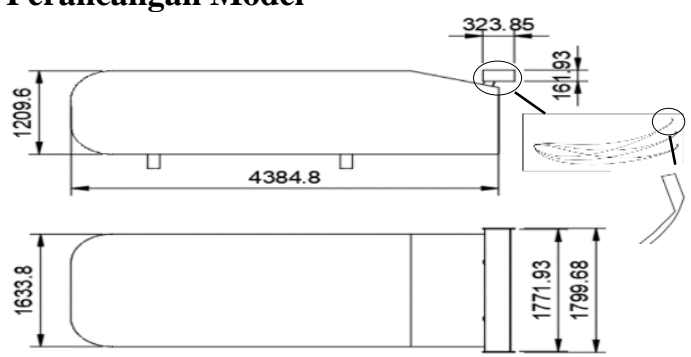

Gambar 1 Hasil desain model

Desain pada model menggunakan Ahmed body yang di scale up ukurannya agar menyerupai dimensi mobil Honda City. Ahmed body dalam penelitian ini di scale up sebesar 4,2 kali dan ditambahkan rear wing dengan Gurney Flap. Berikut adalah dimensi dari model yang digunakan:

Tabel 1

\begin{tabular}{|c|c|}
\hline Desain & Dimensi (mm) \\
\hline Tinggi Ahmed body & 1419,6 \\
\hline Panjang Ahmed body & 4384,8 \\
\hline Lebar Ahmed body & 1633,8 \\
\hline Tinggi endplates & 161,9 \\
\hline Panjang endplates & 323,8 \\
\hline Tebal endplates & 13,8 \\
\hline Tinggi endplates & 161,9 \\
\hline Panjang chord line (C) & 289,8 \\
\hline Lebar airfoil $(\mathrm{W})$ & 1771,9 \\
\hline
\end{tabular}

\section{Boundary Condition \& Meshing}

Boundary condition dari pemodelan ahmed body mengikuti penelitian Banga [1] yakni uniform velocity pada inlet dan uniform pressure pada outlet, symmetry pada sumbu ZY. Batas kondisi yang ditetapkan adalah inlet velocity 40 $\mathrm{m} / \mathrm{s}$, intensitas turbulen $1 \%$ dan rasio viskositas turbulen 10 pada inlet, intensitas turbulen $5 \%$ dan rasio viskositas turbulen adalah 10 pada outlet. Densitas fluida $1,225 \mathrm{~kg} / \mathrm{m} 3$, temperatur 288,16 $\mathrm{K}$ dan viskositas $1,789 \mathrm{e}-0.5 \mathrm{~kg} / \mathrm{ms}$. Sedangkan solution method yang digunakan adalah antara lain coupled, least square cell, standard pressure, turbulence dissipation pada 100 iterasi pertama adalah first order upwind, kemudian second order upwind pada 500 iterasi selanjutnya. Turbulence viscosity factor adalah 0,8 pada 100 iterasi pertama dan 0,95 pada 500 iterasi selanjutnya. 
Untuk domain enclosure yang digunakan mengacu pada penelitian Madharia yakni dengan menggunakan acuan panjang model (L) untuk membuat enclosure. Panjang enclosure terhadap permukaan depan model kedepan adalah 2,4L, kebelakang adalah $6,6 \mathrm{~L}$, keatas adalah $1,5 \mathrm{~L}$ dan lebar adalah 2L [7].

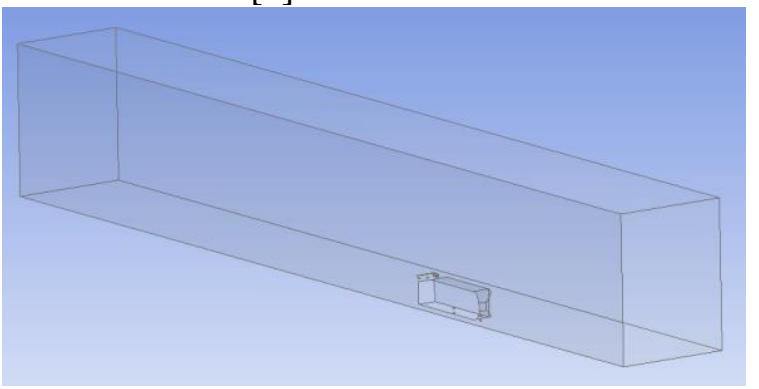

Gambar 2 Enclosure model [8]

Detail mesh pada penelitian ini sebagai berikut relevance center: coarse, smoothing: high, transition: slow, initial seed: Active assembly, min. size: $1 \mathrm{~mm}$, max size: $250 \mathrm{~mm}$, advanced size function: proximity and curvature.

Face sizing dilakukan pada permukaan model. Area tersebut adalah pada roda dengan limited meshing $2 \mathrm{~mm}$ dan ahmed body $10 \mathrm{~mm}$. Body influenced pada ahmed body yaitu wake box, underbody box dan car box. Wake box ditambahkan pada daerah rear slant yang mempunyai pengaruh besar pada wake dan separasi aliran. Underbody box ditambahkan pada daerah roda dan car box ditambahkan menutupi Ahmed body. Batas sizing dari meshing car box $15 \mathrm{~mm}$, wake box $10 \mathrm{~mm}$ dan underbody box $10 \mathrm{~mm}$. Dimensi car box adalah (500x2350x350) mm, wake box (360x750x250) $\mathrm{mm}$ dan underbody-box (50x1100x200) mm. Pengaruh body influence dapat dilihat sebagai berikut.

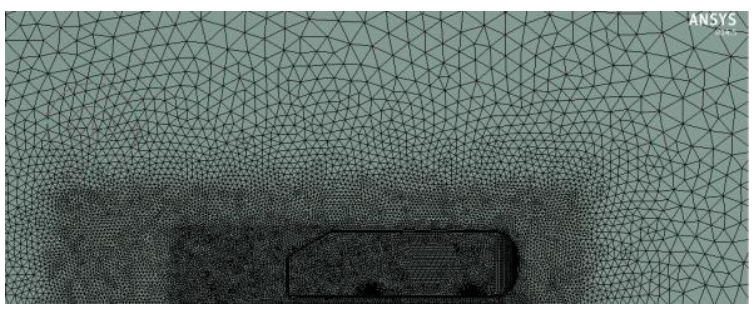

Gambar 3 Pengaruh body influence pada Ahmed body

\section{Validasi Permodelan}

Validasi pada penelitian ini menggunakan Ahmed Body dengan rear slant $15^{\circ}$ pada kecepatan $40 \mathrm{~m} / \mathrm{s}$. Validasi dilakukan untuk mengetahui seberapa valid nya penelitian ini jika dibandingkan dengan penelitian yang sudah ada [1]. Validasi dilakukan dengan membandingkan nilai $C_{L} / C_{D}$ pada rear slant $15^{\circ}$ yang terdapat pada penelitian tersebut dengan yang dilakukan pada penelitian ini.

Selain itu, dilakukan scale up pada model yang diteliti sehingga bisa didapatkan hasil identik dengan mobil Honda City. Setelah dilakukan scale up simulasi, dilakukan pada kecepatan inlet velocity sebesar $90 \mathrm{~km} / \mathrm{jam}$ atau $25 \mathrm{~m} / \mathrm{s}$, Densitas fluida $1,225 \mathrm{~kg} / \mathrm{m} 3$, temperatur $288,16 \mathrm{~K}$ dan viskositas $1,789 \times 10^{-5} \mathrm{~kg} / \mathrm{m} 4$.

Berikut hasil validasi:

Tabel 2 Hasil Validasi Ahmed Body

\begin{tabular}{|c|c|c|c|c|c|c|c|c|c|}
\hline \multicolumn{2}{|c|}{ Penelitian [1] } & \multicolumn{2}{|c|}{ Simulasi } & Error(\%) & \multicolumn{2}{c|}{$\begin{array}{c}\text { Simulasi Scaled } \\
\text { up }\end{array}$} & \multicolumn{2}{c|}{ Error(\%) } \\
\hline$C_{l}$ & $C_{d}$ & $C_{l}$ & $C_{d}$ & $C_{l}$ & $C_{d}$ & $C_{l}$ & $C_{d}$ & $C_{l}$ & $C_{d}$ \\
\hline 0,185001 & 0,246833 & 0,17629 & 0,2587 & 4,7 & 4,8 & 0,18610 & 0,25472 & 0,59 & 2,9 \\
& & & & & & & & & \\
\hline
\end{tabular}

(a)

(b)

(c)

Gambar 4 Hasil Kontur Kecepatan (a)Penelitian Banga (b) Hasil Validasi (c) Hasil Validasi Setelah Scale Up

Tabel 2 menunjukkan perbandingan antara hasil $C_{l}$ dan $C_{d}$ yang didapat sebelum dan sesudah di scale up dengan hasil dari penelitian. Hasilnya, presentase error yang dilakukan pada penelitian ini tidak sampai 5\% baik untuk model Ahmed Body yang sudah di scale up maupun belum. Gambar 4 Menunjukkan hasil distribusi kecepatan antara penelitian [1] dan simulasi yang dilakukan. Hasilnya, distribusi kecepatan yang digambarkan dengan kontur warna tidak berbeda jauh. Sehingga bisa dikatakan penelitian ini sudah valid metode perhitungannya dan dapat dilakukan penambahan airfoil dan Gurney Flap pada model yang akan diteliti.

Setelah metode yang digunakan sudah valid, lalu ditambahkan rear wing denga variasi kemiringan sudut airfoil MSHD sebesar $0^{\circ}, 7,5^{\circ}$ dan $15^{\circ}$ (dihitung dari arah kecepatan udara/sumbu horizontal) dan variasi ketinggian Gurney Flap sebesar 0\%c, 0,5\%c, 1\%c, 1,5\%c, $2 \%$ c untuk setiap variasi kemiringan sudut.

\section{HASIL DAN PEMBAHASAN}

Data yang didapatkan merupakan hasil simulasi yang dilakukan dengan sudut serang $0^{\circ}$, $7,5^{\circ}, 15^{\circ}$ dan ketinggian Gurney Flap yaitu 0\%, $0,5 \%, 1 \%, 1,5 \%$ dan $2 \%$ dari panjang chord line. 
a) Hasil $C_{L}$ pada Model

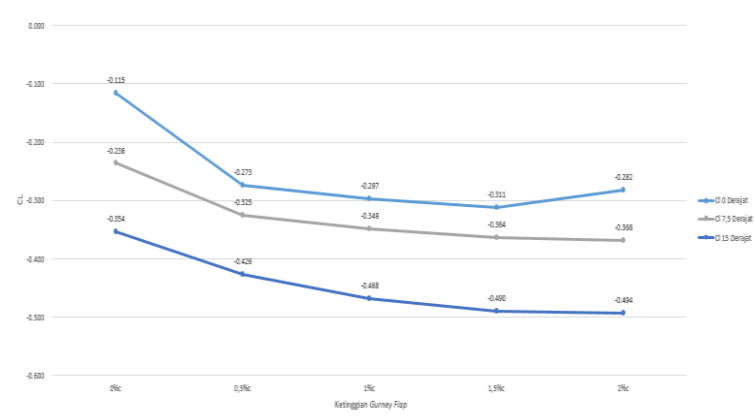

Gambar 4 Koefisien lift tiap model uji

Gambar 4 Menunjukkan hasil koefisien lift $C_{L}$ pada setiap variasi. Nilai $C_{L}$ terendah terdapat pada airfoil dengan kemiringan sudut $15^{\circ}$ dan ketinggian Gurney Flap 2\%c dengan nilai -0.494 dan nilai $C_{L}$ tertinggi terdapat pada airfoil tanpa kemiringan sudut dan tanpa Gurney Flap dengan nilai -0.115. Selain itu, peningkatan nilai koefisien lift $C_{L}$ negatif juga berbanding lurus dengan kemiringan sudut dari airfoil. Dimana airfoil dengan kemiringan sudut $0^{\circ}$ memiliki nilai $C_{L}$ yang lebih tinggi untuk setiap ketinggian Gurney Flap jika dibandingkan dengan airfoil dengan kemiringan sudut $7,5^{\circ}$, dan begitu pula airfoil dengan kemiringan sudut $7,5^{\circ}$ memiliki nilai $C_{L}$ yang lebih tinggi untuk setiap ketinggian Gurney Flap jika dibandingkan dengan airfoil dengan kemiringan sudut $15^{\circ}$. Untuk airfoil dengan kemiringan sudut $0^{\circ}$, nilai $C_{L}$ terendah terdapat pada variasi Gurney Flap dengan ketinggian $1,5 \% \mathrm{c}$, dan pada kemiringan sudut $7,5^{\circ}$ dan $15^{\circ}$ terdapat pada variasi Gurney Flap dengan ketinggian $2 \% \mathrm{c}$.

\section{b) Hasil $\mathrm{C}_{\mathrm{D}}$ pada Model}

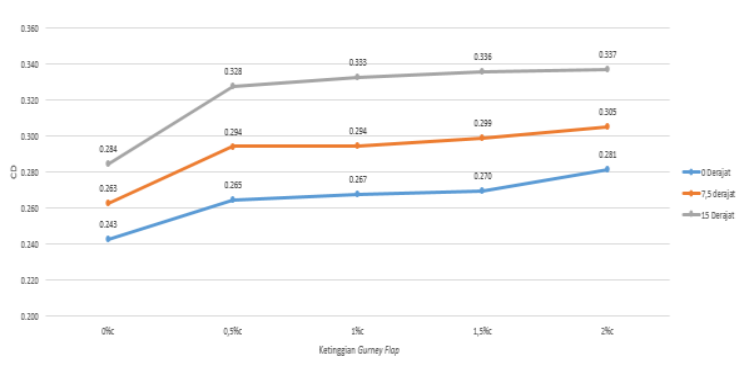

Gambar 5 Koefisien drag tiap model uji

Gambar 5 Menunjukkan hasil koefisien drag $C_{D}$ pada setiap variasi. Nilai $C_{D}$ terendah terdapat pada airfoil tanpa kemiringan sudut dan tanpa Gurney Flap 0\%c dengan nilai 0.237 dan nilai $C_{D}$ tertinggi terdapat pada airfoil dengan kemiringan sudut $15^{\circ}$ dan Gurney Flap dengan ketinggian $2 \%$ c dengan nilai 0.337 . Selain itu, peningkatan nilai $\operatorname{drag} C_{D}$ juga berbanding lurus dengan kemiringan sudut dari airfoil. Dimana airfoil dengan kemiringan sudut $0^{\circ}$ memiliki nilai $C_{D}$ yang lebih rendah untuk setiap ketinggian Gurney Flap jika dibandingkan dengan airfoil dengan kemiringan sudut $7,5^{\circ}$, dan begitu pula airfoil dengan kemiringan sudut $7,5^{\circ}$ memiliki nilai drag $C_{D}$ yang lebih rendah untuk setiap ketinggian Gurney Flap jika dibandingkan dengan airfoil dengan kemiringan sudut $15^{\circ}$. Untuk airfoil dengan kemiringan sudut $0^{\circ}, 7,5^{\circ}$, dan $15^{\circ}$ nilai $\operatorname{drag} C_{D}$ tertinggi terdapat pada variasi Gurney Flap dengan ketinggian 2\%c.

\section{c) Hasil Ratio $C_{L} / C_{D}$ pada Model}

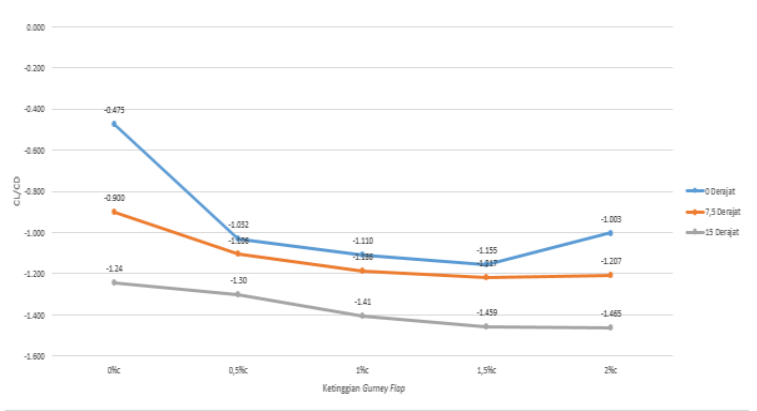

Gambar 6 Koefisien $C_{L} / C_{D}$

Berdasarkan Gambar 6 Semakin tinggi ketinggian Gurney Flap yang diberikan, ternyata tidak selalu menunjukkan hasil yang konsisten. Contohnya pada variasi airfoil dengan ketinggian $2 \%$ c dan tanpa kemiringan sudut $\left(0^{\circ}\right)$ memiliki nilai $\mathrm{C}_{\mathrm{L}} / \mathrm{C}_{\mathrm{D}}$ yang lebih kecil dibandingkan dengan variasi ketinggian lain yang diberikan. Hal tersebut dapat terjadi karena lebih banyaknya gelembung separasi yang terjadi pada aliran di bagian leading edge dibandingkan aliran yang berpisah secara bertahap dari leading edge menuju ke trailing edge [6]. Nilai $C_{L} / C_{D}$ terendah terdapat pada airfoil dengan kemiringan sudut $15^{\circ}$ dan ketinggian Gurney Flap sebesar $2 \%$ c dengan nilai -1.465 .

\section{d) Perbandingan Hasil Uji Pada Distribusi Kecepatan dan Tekanan}

Mengamati karakteristik aerodinamika pada suatu benda dapat dengan cara menganalisa distribusi kecepatan maupun tekanan yang didapat dari hasil simulasi. Distribusi kecepatan maupun tekanan pada simulasi kali ini digambarkan dengan kontur warna yang berbeda beda. Pada bagian ini, nilai distribusi kecepatan maupun tekanan yang rendah maupun tinggi, dapat diwakilkan dengan kontur warna yang berbeda beda. Berikut adalah kontur kecepatan 
dan tekanan dari hasil simulasi pada sudut serang $15^{\circ}$ dan ketinggian Gurney Flap 0\%c, 0,5\%c, $1 \%$ c, $1,5 \%$ c dan $2 \%$ c.

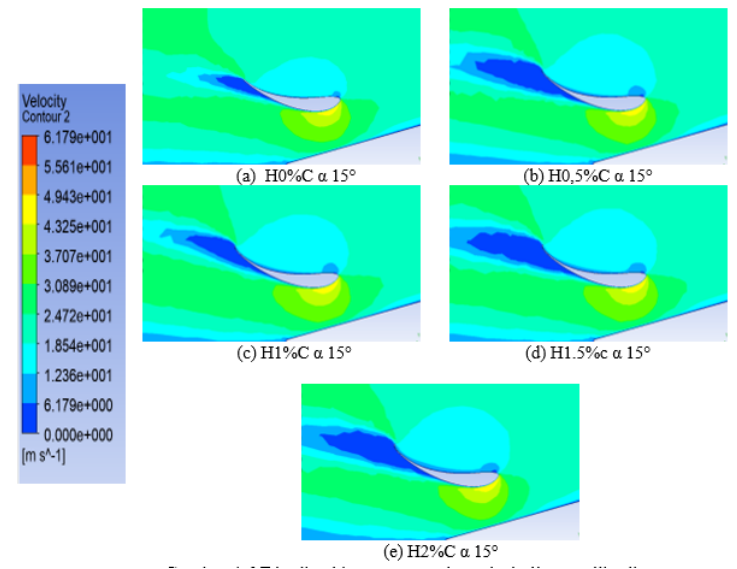

Gambar 7 Hasil kontur kecepatan

Gambar 7 menunjukkan perbedaan distribusi kecepatan yang diberikan oleh airfoil tanpa Gurney Flap dan dengan Gurney Flap. Berdasarkan gambar tersebut, dapat dilihat bahwa airfoil dengan penambahan Gurney Flap mampu memberikan pengaruh yang cukup besar terhadap distribusi kecepatan pada airfoil. Bagian atas airfoil, memiliki kontur kecepatan lebih rendah dibandingkan bagian bawah airfoil. Hal ini ditunjukkan dengan bagian atas airfoil berwarna biru dengan kecepatan yang rendah berkisar antara $0 \mathrm{~m} / \mathrm{s}$ sampai $18,54 \mathrm{~m} / \mathrm{s}$ sementara bagian bawah airfoil yang lebih tinggi kecepatannya berada di kecepatan $24,72 \mathrm{~m} / \mathrm{s}$ sampai 49,43m/s. Berdasarkan gambar, airfoil yang diberikan Gurney Flap dengan ketinggian $2 \%$ c memiliki kontur warna biru muda yang paling besar luasannya, sehingga dianggap memberikan perubahan paling besar pada karakteristik airfoil.

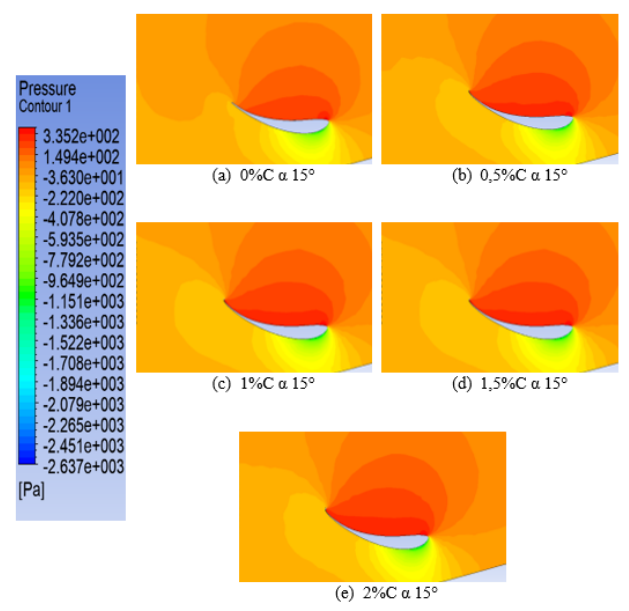

Gambar 8 Hasil kontur tekanan
Gambar 8 menunjukkan hasil distribusi tekanan yang didapat dari variasi uji yang diberikan. Kontur tekanan menjelaskan tentang bagian distribusi tekanan yang dihasilkan oleh variasi uji mulai dari tekanan ter tinggi hingga ter rendah. Tekanan tinggi dalam gambar tersebut direpresentasikan dengan warna oranye-merah dengan nilai $-0,363 \mathrm{~Pa}$ sampai $335,2 \mathrm{~Pa}$, sedangkan untuk daerah bertekanan rendah diberikan warna hijau-kuning dengan nilai 0,001151 Pa sampai -0,034078 Pa. Berdasarkan gambar, terlihat sekali perbedaan distribusi tekanan antara airfoil yang ditambahkan Gurney Flap dan yang tidak. Untuk bagian airfoil yang tidak diberikan Gurney Flap memiliki daerah yang berwarna oranye-merah jauh lebih luas pada bagian atas airfoil dibandingkan dengan airfoil tanpa Gurney Flap.

Berdasarkan hasil simulasi, nilai koefisien lift negatif terus naik nilainya sebanding dengan variasi ketinggian Gurney Flap yang diberikan hingga mencapai nilai 0.494. Hal tersebut dapat dijelaskan oleh Gambar 7 dimana daerah yang memiliki kecepatan yang rendah di bagian atas airfoil paling besar daerahnya dibandingkan dengan variasi lainnya, dan begitu pula oleh Gambar 7 dimana daerah yang memiliki tekanan yang tinggi pada bagian atas airfoil paling besar daerahnya dibandingkan dengan variasi lainnya. Hal tersebut terjadi sesuai dengan hukum Bernoulli dimana ada kecepatan yang rendah maka akan menghasilkan tekanan yang tinggi atau dalam hal ini dapat menciptakan downforce. Selain itu, perbedaan tekanan antara kedua sisi airfoil juga menimbulkan adanya dragforce yang merupakan suatu kerugian. Hal ini dibuktikan dengan data hasil simulasi bahwa ada peningkatan nilai koefisien drag hingga mencapai nilai 0.337 .

\section{e) Analisa Pola Aliran Udara}

Pada bagian ini akan dilakukan perbandingan pola aliran udara antar variasi uji yang diberikan. Aliran udara akan di analisa untuk mengetahui karakteristiknya pada setiap variasi uji yang diberikan, dan apakah nilainya sesuai dengan teori yang ada. Pada penambahan airfoil dan Gurney Flap tentu akan sangat berpengaruh pada pola aliran udara, terutama dalam terbentuknya separasi pada aliran udara [9]. Dalam analisa ini terdapat Streamline yang merupakan suatu bentuk aliran yang arah alirannya menghantam mobil, atau berlawanan arah dengan permukaan mobil. 

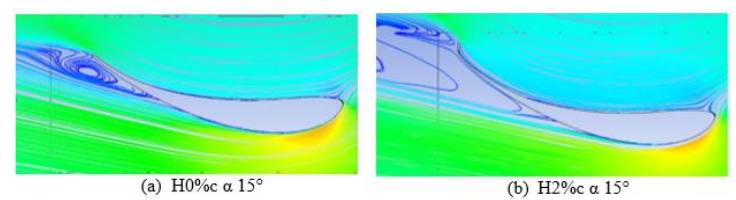

Gambar 9 Hasil pola aliran udara

Gambar 9 Menunjukkan perbedaan karakteristik terhadap variasi uji yang diberikan terhadap pola aliran. Pada analisa ini, airfoil dengan kemiringan sudut $15^{\circ}$ dan Gurney Flap dengan ketinggian $2 \%$ c berhasil menciptakan separasi aliran dan membuat aliran mengikuti bentuk dari airfoil mulai dari bagian leading edge sampai trailing edge. Perbandingan yang paling terlihat antar variasi uji adalah ukuran dari gelembung separasi atau lapisan wake yang ada. Pada airfoil tanpa Gurney Flap, sudah mulai terjadi wake sehingga menciptakan drag yang bentuknya semakin besar seiring dengan bertambahnya ketinggian dari variasi Gurney Flap yang dbierikan. Disi lain, semakin tinggi Gurney Flap yang diberikan, maka semakin tinggi pula aliran terangkat dan semakin baik pula separasi yang terjadi sehingga nilai koefisien lift $\left(\mathrm{C}_{\mathrm{L}}\right)$ negatif akan semakin tinggi. Hal ini terlihat pada airfoil dengan ketinggian Gurney Flap 2\%c dimana ketika terjadi separasi, aliran di bagian bawah airfoil mulai naik secara bertahap mengikuti bentuk dari airfoil.

\section{KESIMPULAN}

Berdasarkan perancangan desain Ahmed body dan airfoil jenis MSHD dan simulasi aerodinamika, maka didapatkan kesimpulan sebagai berikut:

1. Gurney Flap mampu meningkatkan nilai koefisien lift $C_{L}$ negatif dengan nilai yang cukup besar, dan peningkatan nilai koefisien lift negatif sebanding dengan bertambahnya ketinggian variasi Gurney Flap yang diberikan. Nilai koefisien lift negatif tertinggi terdapat pada pada airfoil MSHD dengan kemiringan sudut $15^{\circ}$ dan ketinggian Gurney Flap 2\%C dengan nilai 0.499 .

2. Selain mampu menambahkan nilai koefisien lift negatif, Gurney Flap juga dapat meningkatkan nilai koefisien drag $C_{D}$ yang mana merupakan faktor yang merugikan. Nilai peningkatan nilai koefisien drag sebanding dengan bertambahnya ketinggian variasi Gurney Flap yang diberikan. Nilai koefisien drag tertinggi terdapat pada pada airfoil MSHD dengan kemiringan sudut $15^{\circ}$ dan ketinggian Gurney Flap 2\%C dengan nilai 0.337 .

\section{Daftar Pustaka}

[1] S. Banga, N. A. Ansari, S. Sharma, and R. S. Dungriyal, "CFD Simulation of Flow around External Vehicle : Ahmed Body," vol. 12, no. 4, pp. 87-94, 2015.

[2] A. T. McDonald, Robert W. Fox, Philip J. Pritchard, "Introduction to Fluid Mechanics, 8th ed. Manhattan", 2011.

[3] E. L. Houghton and N. B. Carruthers, "Aerodynamics for engineering students. Third edition," 1982.

[4] S. S. PAKKAM, "High Downforce Aerodynamics for Motorsports," 2011.

[5] Ben Agathangelou, Mike Gascoyne, "Aerodynamic Design Considerations of a Formula 1 Racing Car," no. 724, 2018.

[6] J. J. Wang, Y. C. Li, and K. Choi, “Gurney Flap - Lift enhancement, mechanisms and applications," vol. 44, pp. 22-47, 2008.

[7] P. Madharia, M. M. Tiwari, K. Ravi, and A. General, "Computational Simulation of Ahmed Body with Varying Nose radius , Ground height \& Rear Slant angle," Int. J. Res. Appl. Sci. Eng. Technol., vol. 3, no. 5, pp. 925-932, 2015.

[8] S. Kesarwani, Y. Jayas, and V. Chhalotre, "CFD Analysis Of Flow Processes Around The Reference Ahmed Vehicle Model," Int. J. Eng. , vol. 3, no. 3, pp. 775-780, 2014.

[9] L. Tianshu and J. Montefort, "Thin-airfoil theoretical interpretation for Gurney Flap lift enhancement," J. Aircr., vol. 44, no. 2, pp. 667-671, 2007. 